\title{
The Potential to Develop Regions Based on Salt Commodities through Geographic Information System (GIS) in the Jeneponto Regency
}

\author{
Muhammad Anshar ${ }^{1}$, Lukman ${ }^{2}$, Junas $\mathrm{S}^{3}$ \\ ${ }^{123}$ Department of Urban and Regional Planning Engineering, Faculty of Science and \\ Technology, Universitas Islam Negeri Alauddin Makassar, Indonesia 92113 \\ \{muhammad.anshar@uin-alauddin.ac.id ${ }^{1}$, Allukman@gmail.com², junaspwk11@gmail.com³
}

\begin{abstract}
This study aims to analyze the potential development of salt-based areas in Jeneponto Regency. The method of analysis used is descriptive analysis and mapping analysis based on Geographic Information System (GIS). The results from the research show that Jeneponto Regency, in particular Bangkala district, has the potential for basic physical aspects including geographical location, topography and slope, climatology, geology and soil types, and potential nonphysical aspects including government policies and community institutions. This potential has led to the development of salt-based commodity areas in Jeneponto Regency.
\end{abstract}

Keywords: The Potential, Develop Regions, Salt Commodities.

\section{Introduction}

National ideals of the Republic of Indonesia is to realize the Unitary State of the Republic of Indonesia which is independent, united, sovereign, fair and prosperous. The acceleration of regional development left also be part of the realization of the national goals set forth in the Fourth Paragraph The opening of the 1945 constitution, namely to protect the whole Indonesian Nation and the entire the spilled blood of Indonesia, to promote the general welfare, the intellectual life of the nation, and participate implement world order based on independence, lasting peace, and social justice [1].

Indonesia is the largest archipelago Country in the world with 17.480 with a number of the big island and more than 1,000 small islands that spread from Sabang until Merauke. These conditions make the coastal areas Indonesia has the potential natural resources high such as mangroves, coral reefs (coral reefs) and seagrass beds (sea grass beds) as well as resources natural coastal [2].

Allotment cultivation of the coastal region was formed one of them for the cultivation of salt. Salt is one of the strategic commodities of national in the field of marine. Extensive salt ponds in the Indonesia about 30.786 hectares and are located in different places in Indonesia, the largest on the island of Java and Madura [3].

The policy of spatial planning of Jeneponto Regency include, development of cultivation area in accordance with the carrying capacity of the environment in an effort to realize the space region districts that meet the development needs of economic, social, and cultural, which environmentally friendly to achieve the welfare of the community [4]. 
Bangkala district one of the sub-district producer of salt in the Jeneponto Regency, with acreage farmed by 622,66 ha and the amount of labor as much as 2.345 soul, then supported by the physical conditions and climate of the region as well as the suitability of land for cultivation of salt ponds broad enough to allow to continue to be developed.[5] But the data Jeneponto in the figure it can be seen, the significant decrease for the production of salt, drop that reached the $50 \%$ shows that the potential of the salt is not quite maximized by government. These circumstances clearly have an impact on the social conditions of ekomi community of local fishermen salt also resulted in the development of the region. This issue has also become a national issue because the potential for salt that is abundant in the region of Indonesia but the government still has to import salt.

Based on the problems above, the researcher interested to do research with the title "the Potential to Develop Regions Based on Salt Commodities Through Geographic Information System (GIS) in the Jeneponto Regency"

\section{Material and Methods}

This type of research is qualitative descriptive with the location of this study conducted in Bangkala District, Jeneponto Regency with the object of research namely the Potential to Develop Regions Based on Salt Commodities Through Geographic Information System (GIS) in the Jeneponto Regency.

The type of data used in this study is in the form of quantitative data and qualitative data which are considered to be relevant to research. Sources of data needed include primary data and secondary data. And primary is data obtained from individuals or individuals by conducting observations and interviews. Secondary data is data obtained from the offices of agencies or related institutions and data from the results of previous studies that are standard data, while the secondary data in the form of: basic physical aspects data.

Techniques for collecting data through field observations and literature review. To find out how the potential for developing livestock-based rural resources in Pattuku Village, Bontocani district, Bone Regency by looking at the potential of livestock owned and also referring to the basic physical aspects of the area using GIS-based mapping analysis followed by descriptive analysis with regional resource research variables (basic physical aspects) with the geographical location, topographic indicators, climatology, geological and the type of soil and the non physical aspect with indicator : government policy, the institutional community.

\section{Results and Discussion}

\subsection{A General Overview Of The Study Site}

Administratively, the government of Bangkala district consists of 14 territory of the Village/kelurahan, among the five Villages/Kelurahan that has a beach then in this research we only take 5 village/sub district in Bangkala district because of the great potential in the development of the land area of the salt ponds, namely the village of bahari beach, village of pallengu, village Bontomarannu, village punagayya, village mallasoro. For more details can be seen in the following table this:

Tabel 1. Area of Bangkala District According To The Village/Kelurahan The Year 2018.

\begin{tabular}{|c|c|c|c|}
\hline No & $\begin{array}{c}\text { Village/Sub } \\
\text { District }\end{array}$ & Area (Km2) & Persentage (\%) \\
\hline 1 & Mallasoro & 795 & 6,53 \\
\hline
\end{tabular}




\begin{tabular}{|c|l|c|c|}
\hline 2 & Punagayya & 840 & 6,90 \\
\hline 3 & Bontomarannu & 838 & 6,88 \\
\hline 4 & Pantai Bahari & 500 & 4,10 \\
\hline 5 & Pallengu & 500 & 4,10 \\
\hline \multicolumn{2}{|c|}{ Amount } & 3.473 & 100,00 \\
\hline
\end{tabular}

Source : BPS . Kecamatan Bangkala Dalam Angka, 2018.

Below, you can see the map of administrative Jeneponto Regency as follows :

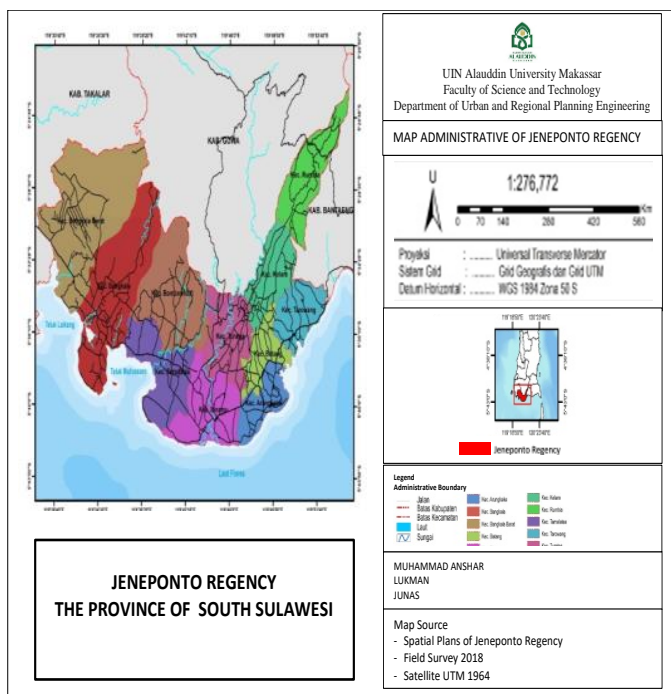

. Figure 1. Administrative Map of Jeneponto Regency

The location of the cultivation salt in Bangkala district naturally formed and shaped- plots are stratified, where each area per plot is generally $4 \mathrm{~m} \times 10 \mathrm{~m}$ to $3 \mathrm{~m} \times 7 \mathrm{~m}$.

Below, you can see a map of the administrative Bangkala District as follows : 


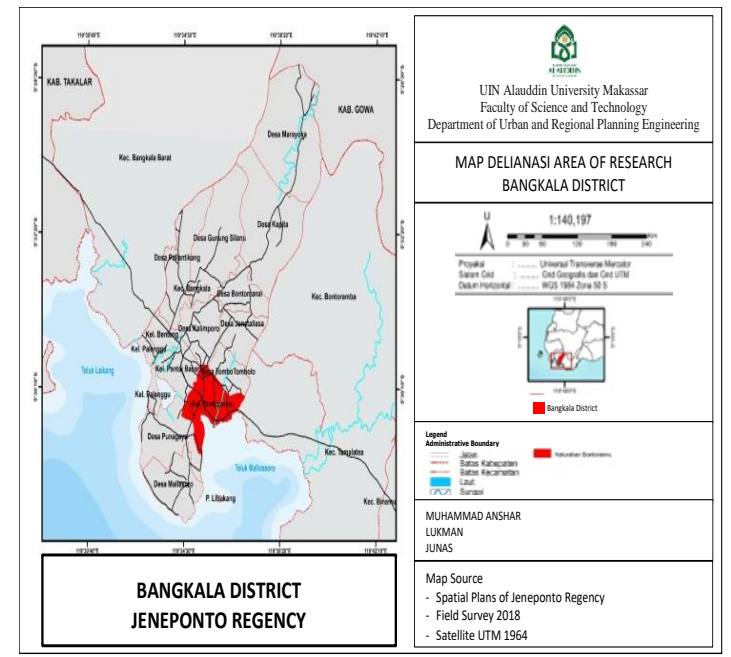

Figure 2. Administrative Map of Bangkala District

\subsection{The Potential For The Development Of Region-Based Commodity Salt}

\subsubsection{The Potential Of The Physical Aspects Of Basic}

\subsubsection{Geographic}

Bangkala district is one of the 11 (Eleven) districts in the Jeneponto Regency which is bordered by Gowa Regency on the north, District Tamalatea in to the east, Bangkala Barat district in the west and the Flores Sea in the south. In administration Bangkala district have as many as 14 (Fourteen) Villages/kelurahan. 5 (Five) Villages/sub district in Bangkala district is not the beach area and 9 (Nine) Other villages is the beach area. [7]

\subsubsection{Topography and Slope}

Bangkala district is one of the districts located in the lowlands that located at an altitude of 0-500 meters above sea level. In terms of slope Bangkala district located on a slope of 0-8. These conditions are still appropriate in the land use and increase the production of salt.

Below, you can see a map of the Topography and Slope of the Bangkala District Jeneponto Regency is as follows. 


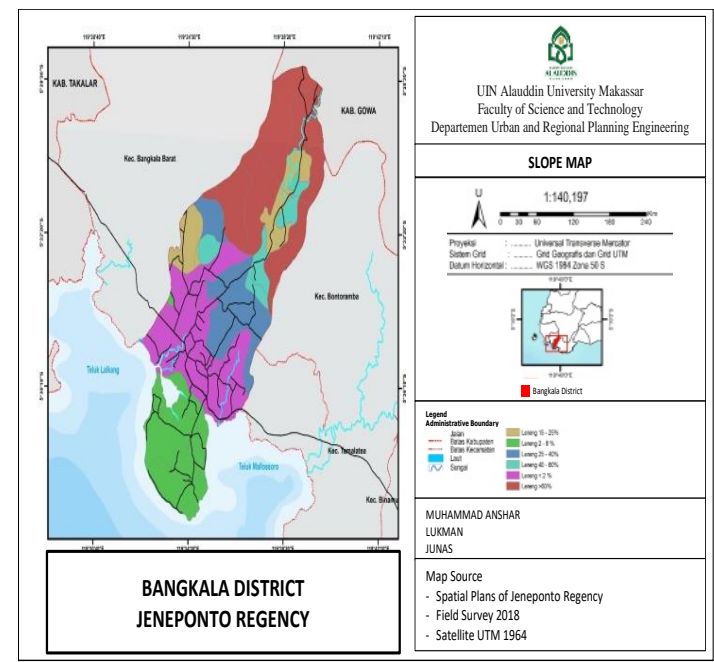

Figure 3. Topographic and slope map of Bangkala District

\subsubsection{Climatology}

The state climatology affects three aspects that greatly affect the space in a region, namely the season, the air temperature and precipitation.Bangkala district have a temperature range between $30^{\circ} \mathrm{C}-40^{\circ} \mathrm{C}$ with rainfall of distances $1200-3200 \mathrm{~mm} /$ year. The dry season occurs between april until October.

\subsubsection{Geology and Soil Type}

There are two types of land in Bangkala district namely Alluvium and sand, where the land alluvium suitable for plantations, agriculture. While the soil is sand formed from the unit of igneous rocks and rock sendimen, which is suitable and appropriate for the land use and to optimize the production of salt. [8]

Below, you can see the map Soil Type Bangkala District Jeneponto Regency as here. 


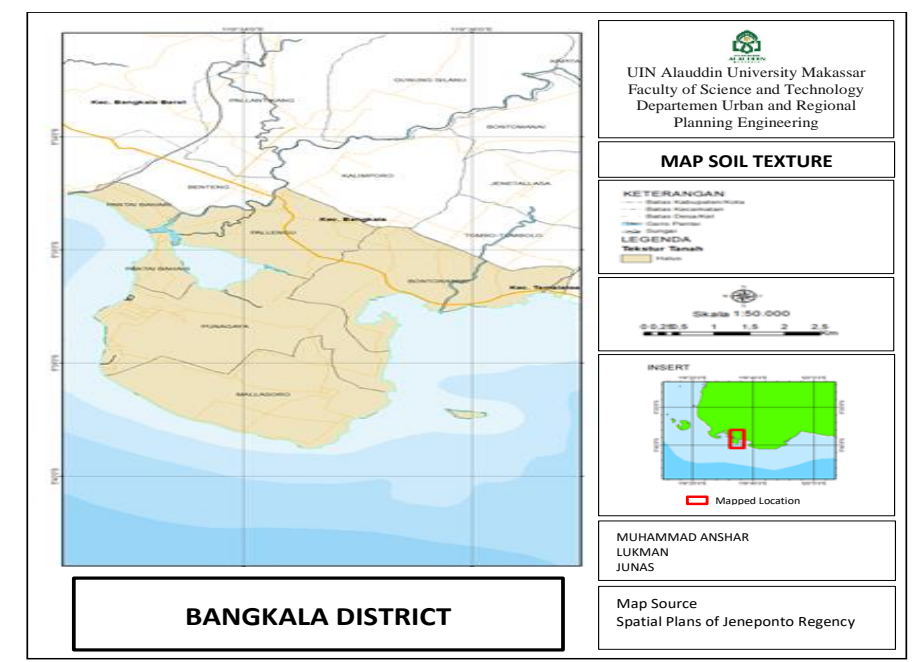

Figure 4. Soil texture map of Bangkala District

\subsection{The Potential Of The Non Physical Aspects}

\subsubsection{Government Policy}

\subsubsection{The Presidential Regulation About The National Strategy For The Acceleration Of Regional Development Left behind}

Government policy through the accelerated development of disadvantaged regions 2015-2019 which Jeneponto Regency, Sulawesi Region entered the list of Underdeveloped Districts get priority handling with the main causes of backwardness, namely human resources, the ability the financial area as well as the characteristics of the area.

\subsubsection{Program and financing the construction of short-term 2018-2020}

The Program of the Agency for Development of Infrastructure of the Ministry of Public works and Housing directed to the integration of regional development with infrastructure Public works and Public Housing in particular in the development of the industry in Jeneponto regency with activities between other road construction and bridge urban and inter -urban Jeneponto.[9]

\subsubsection{Spatial Plan Of Jeneponto Regency}

The purpose of the spatial Plan of the Region of Jeneponto regency is to realize the space region districts that meet the development needs of economic, social, and cultural, which environmentally friendly.[10]. Development needs to consider the dimensions of the region optimize land resources with the creation of opportunities allocation of investment efficiently, 
the synergy between the region, and the optimization of the resources of the region towards the achievement of the welfare of the community. [11]

\subsubsection{The Institutional Community}

The institutional community, especially farmers developed to meet the eligibility business economies of scale and business efficiency. [12] Institutional are presented in the maximize its function as a business unit of a provider of facilities and infrastructure of production, units Farm/ Production unit, processing activities, business unit marketing and business unit micro finance. [13]

Farmer groups are hereinafter abbreviated as $\mathrm{Fg}$ is set in the empowerment of farmers/farmers formed on the basis of similarity of interests, similarity of environmental conditions (social, economic, resources) and familiarity. [14]. The presence of farmer groups/the ponds expected to be able to improve and develop member businesses. [15] In The District Bangkala there are 11 group of salt farmers (poktan). A group of salt farmers is the association of the tenants of salt, which has an important role in the development of efforts such as the development of the organizer, critical power, and business cooperation. The results of the research show in Bangkala distric primarily in the cultivation of salt there are 9 (Nine) the tenants of salt consists of 15-25 members.

\section{Conclusion}

Jeneponto regency, especially the Bangkala District have the potential aspect of the basic physical includes geographical location,topography and slope, climatology, geology and soil type as well as the potential the non physical aspects include government policy and institutional community. The potential push in the development of region-based commodity salt in Jeneponto regency.

\section{References}

[1] Peraturan Presiden Nomor 21 Tahun 2018 tentang Strategi Nasional Percepatan Pembangunan Daerah Tertinggal Tahun 2015-2019. Jakarta

[2] Lukman, 2018. Pengembangan Wilayah Kecamatan Bangkala Berbasis Budidaya Tambak Garam di Kabupaten Jeneponto. Fakultas Sains \& Teknologi UIN Alauddin Makassar.

[3] Kementerian Perdagangan Republik Indonesia bekerja sama dengan Al Mawardi Prima Anggota IKAPI DKI Jaya,2016. Info Komoditi Garam. Badan Pengkajian dan Pengembangan Perdagangan. Jakarta.

[4] Peraturan Daerah Kabupaten Jeneponto Nomor 1 Tahun 2012. Rencana Tata Ruang Wilayah Kabupaten Jeneponto Tahun 2012-2031. Bappeda KabupatenJeneponto, Jeneponto.

[5] Badan Pusat Statistik (BPS) Kabupaten Jeneponto Dalam Angka tahun 2018

[6] Muhammad Anshar et al. The potential for rural resources development, specifically livestock commodities based on Geographic Information System (GIS) in Patukku Village, Bontocani District, Bone Regency. IOP Conf. doi:10.1088/1755-1315/247/1/012076 1 (2019) 
[7] Badan Pusat Statistik (BPS) Kabupaten Jeneponto. Kecamatan Bangkala Dalam Angka 2018.

[8] Junas, 2018. Pengembangan Lahan Pertambakan Garam dalam Meningkatkan Produktivitas Garam di Kecamatan Bangkala Kabupaten Jeneponto. Fakultas Sains \& Teknologi UIN Alauddin Makassar.

[9] Kementerian Pekerjaan Umum dan Perumahan Rakyat, 2017. Sinkronisasi Program dan Pembiayaan Pembangunan Jangka Pendek 2018-2020. Pusat Pemrograman dan Evaluasi Keterpaduan Infrastruktur Wilayah. Jakarta.

[10] Kementerian Riset, Teknologi dan Pendidikan Tinggi RI.2018. Pengelolaan Program Klaster Inovasi dan Permasalahannya. Direktorat Sistem Inovasi Direktorat Jenderal Penguatan Inovasi. Jakarta.

[11 ]Dinas Kelautan dan Perikanan Prov.Sulawesi Selatan . Rencana Strategis Tahun 20132018. Makassar

[12] W Sumekar, A N Al-Baarri1 and E Kurnianto. 2018. Prospect for the development of salted egg agro industry: an analysis on marketing distribution aspect. Doi :10.1088/17551315/102/1/012005.

[13] Wahida,N , Anshar,M. 2018, Peran Gabungan Kelompok Tani dalam Pengembangan Wilayah Perdesaan di desa Pattuku Kecamatan Bontocani Kabupaten Bone. Fakultas Sains \& Teknologi UIN Alauddin Makassar.

[14] Astati et al. Empowerment and increasing the scale of beef cattle in Bonto Manai Village Bisappu District Bantaeng Regency. IOP Conf. Doi : 10.1088/17551315/247/1/012059.(2019)

[15] Jenudin., 2017, Peranan Kelompok Tani Sumber Harapan dalam Meningkatkan Kesejahteraan Anggota Kelompok Tani Sumber Harapan Desa Tenajar Kidul Kecamatan Kertasemaya Kabupaten Indramayu, Perpustakaan IAIN Syekh Nurjati Cirebon, 1. 